\title{
SPONTANEOUS BACTERIAL EMPYEMA IN CIRRHOTIC PATIENTS WITH HEPATIC HYDROTHORAX.
}

1. MBBS, FCPS

Assistant Professor

Department of Gastroenterology

Isra University Hospital.

2. MBBS, FCPS

Assistant Professor

Department of Gastroenterology

Isra University Hospital.

3. MBBS, FCPS

Assistant Professor

Department of Gastroenterology Isra University Hospital.

4. MBB, FCPS

Senior Registrar

Bhitai Dental and Medical College

Mirpurkhas

Correspondence Address:

Dr. Prem Kumar

Department of Gastroenterology

Isra University Hospital.

rajprem1980@yahoo.com

Article received on:

22/10/2018

Accepted for publication:

$31 / 07 / 2019$

\begin{abstract}
Ehsan Rahim Memon ${ }^{1}$, Prem Kumar Maheshwari², Shabana Lakho ${ }^{3}$, Zeeshan ul Haque ${ }^{4}$
\end{abstract}
\begin{abstract}
Objectives: To determine the frequency of spontaneous bacterial empyema in cirrhotic patients with hepatic hydrothorax. Study Design: Descriptive cross sectional study. Setting: Conducted in gastroenterology unit at Isra University Hospital, Hyderabad. Periods: One year from April 2016 to March 2017. Material \& Methods: Sample of 174 patients of Hepatic Hydrothorax was taken. Patients were of both gender and age $\geq 18$ years, having diagnosed cirrhosis since last 5 years and currently having child class $B$ \& $C$ severity were included. Hepatic hydrothorax was confirmed on ultrasound chest. After aseptic measures $50 \mathrm{ml}$ of pleural fluid was aspirated and sent to Isra University Hospital laboratory following the ultrasound guidelines. Spontaneous bacterial empyema was assessed as "polymorph nuclear cell count" more than 500 cells $/ \mathrm{mm}^{3}$ or +ve culture with PMN cell count more than 250 cells/ $\mathrm{mm}^{3}$ without parapneumonic effusion. All the data was recorded in the proforma. Results: The mean \pm SD age of patients was $53.52 \pm 5.52$ years. Males were $60.92 \%$ while $39.08 \%$ were females. The frequency of spontaneous bacterial empyema was about $14.9 \%$. Frequency of spontaneous bacterial empyema was little more in male gender than females ( $p$ value $=0.391$ ), while it was significantly increased with increasing age as most common in age group of 61-65 years $(p-v a l u e=0.017$ ). Conclusion: It was concluded that spontaneous bacterial empyema in cirrhosis patients was $14.9 \%$.
\end{abstract}

Key words: Cirrhosis, Hepatic Hydrothorax, Spontaneous Bacterial Empyema.

Article Citation: Memon ER, Maheshwari PK, Lakho S, Zeeshan ul Haque. Spontaneous Bacterial Empyema in Cirrhotic patients with Hepatic hydrothorax. Professional Med J 2020; 27(1):115-119. DOI: $10.29309 / \mathrm{TPMJ} / 2020.27 .1 .3652$

\section{INTRODUCTION}

Spontaneous bacterial empyema (SBEM) is a well-known complication of cirrhosis and is defined as when pleural fluid spontaneously gets infected and shows a diverse complication of hepatic hydrothorax. ${ }^{1}$ Sometimes in certain cases in the absence of pus or abscess in pleural cavity, this term may be confusing and indeed, the pathogenesis, clinical course and management of SBEM is quite different in patients in which empyema develops secondary to pneumonia. Therefore, some authors named it spontaneous bacterial pleuritis. ${ }^{2}$ Hepatic hydrothorax is low in protein concentration fluid (transudative), usually amount of fluid is greater than 500 milliliters, and cirrhotic patients accompany with portal hypertension without basic cardiovascular and pneumonic illnesses. ${ }^{3}$ Hepatic hydrothorax requires the same treatment as in ascites; restriction to salt, use of appropriate diuretics, and fluid drainage. ${ }^{4}$ The prevalence of spontaneous bacterial empyema was noticed in about $13 \%$ of cirrhotic patients with hepatic hydrothorax. ${ }^{2}$ Frequency of fatality in these patients is quite high, early recognition is very important to start proper management to reduce the risk of death. ${ }^{5}$ The prevalence of hepatic hydrothorax in patients with underlying cirrhosis is estimated to be about $5 \%$. In about $85 \%$ of these cases pleural effusion occurs on right side of the chest but it can also be bilateral.

Rarely the left sided effusion may occur, it can even occur in the absence of ascites as well.6,7 Development of pleural effusion involves several mechanisms in cirrhotic patients, change in splanchnic circulation, rise in the concentration of nitric oxide (NO) in splanchnic circulation, decrease albumin concentration in blood, increased flow along with raised pressure in 
thoracic duct, and azygos veins and portal hypertension are usual in patients having cirrhosis and these all are the main contributor in the development of ascites and pleural effusion. ${ }^{8}$ Cardenas et al. 2004 explains the development of hepatic hydrothorax, which occurs when ascetic fluid ascends upwards through diaphragmatic defects from the peritoneal cavity. ${ }^{8}$ Chen et al. 2003 mentioned in his study that low protein content in ascites, low ascetic fluid opsonic activity, low C3 concentration, and hepatic insufficiency are the major contributing factors for the development of SBP and recurrence of SBEP. ${ }^{9}$ Prevalence of chronic liver disorders in Pakistan is on verge and a large number of these cirrhotic patients are facing multiple complications of cirrhosis like SBEP. ${ }^{10,11}$ The about large number of these patients in our country is lacking. The result of this study will help make strategies to assess and treat such patients promptly in order to prevent avoidable morbidity and mortality among such patients.

\section{MATERIAL \& METHODS}

This descriptive cross-sectional study was conducted at Gastroenterology Department of Isra University Hospital Sindh. One year from April 2016 to March 2017. The sample size for the study was calculated on the basis of prevalence of SBEM in cirrhotic $13 \% .^{2}$ A total 174 patients were included in this study based on $95 \%$ confidence interval and $5 \%$ margin of error. All consenting cirrhotic patients of Hepatic Hydrothorax, duration of cirrhosis diagnosis $>5$ years, severity of disease as per Child Pugh class ( $B$ and $C$ only), age $\geq$ 18 years and either of gender were included in the study after taking informed consent. Patients who did not consent to participate in the study and with age $\leq 18$ years were excluded. All the patients underwent complete clinical examination and required laboratory investigations were done. Hepatic hydrothorax was confirmed on ultrasound and X-ray of chest. $50 \mathrm{ml}$ fluid of pleural effusion was aspirated from each patient by using the transthoracic approach, taking ultrasound direction, where needed.

After aseptic measures $50 \mathrm{ml}$ of pleural fluid was aspirated and sent to Isra University Hospital laboratory following the ultrasound guidelines. SBEM was assessed positive in the presence of pleural fluid with "polymorph nuclear cell count" more than 500 cells $/ \mathrm{mm}^{3}$ or +ve culture with PMN cell count more than 250 cells $/ \mathrm{mm}^{3}$ without parapneumonic effusion. All the data was recorded in the proforma. Data was analyzed by using the SPSS version 16.0. Frequency and percentage were calculated for categorical variables. Mean and standard deviation were calculated for numerical variables. Effects modifiers like and gender by stratification were controlled for outcome variable. Chi-square test was applied and a p-value $<0.05$ was considered as significant.

\section{RESULTS}

Total 174 patients were enrolled; their mean age was $53.52 \pm 5.52$ years with range of $40-65$ years. Most common age group was 51-60 years among $65.5 \%$ patients, followed by $41-50$ years in $29.3 \%$, $61-65$ years in $4.6 \%$ and only one patient was less than 40 years. Males were in majority $60.9 \%$ and females were $39.1 \%$. Mild ascites was found in $47.1 \%$ patients, $24.7 \%$ had moderate to severe ascites, while $28.2 \%$ were without ascites. More than half of patients (52.9\%) did not found to have hepatic encephalopathy, $36.2 \%$ had grade 1-2 hepatic encephalopathy: while $10.9 \%$ patients had grade 3-4 hepatic encephalopathy, results showed in Table-l.

Regarding the frequency of spontaneous bacterial empyema in Patients of hydrothorax. Frequency of spontaneous bacterial empyema was little more in male gender than females (16\% versus $13.2 \%$ with a non-significant $p$ value $=0.391$ ) Frequency of SBEM significantly increased with increasing age (from zero percent among patients of up to 40 years age to $42.9 \%$ among patients of $61-65$ years age) $(p$ value $=0.017$; Table-II . 


\begin{tabular}{|l|c|c|c|}
\hline \multicolumn{1}{|c|}{ Variables } & Frequency & Percent \\
\hline \multirow{4}{*}{ Age } & $<40$ years & 1 & $0.6 \%$ \\
groups & $41-50$ years & 51 & $29.3 \%$ \\
& $51-60$ years & 114 & $65.5 \%$ \\
& 61-65 years & 8 & $4.6 \%$ \\
\hline \multirow{3}{*}{ Gender } & Total & 174 & $100.0 \%$ \\
\hline & Male & 106 & $60.9 \%$ \\
\hline Ascites & Female & 68 & $39.1 \%$ \\
& Total & 174 & $100.0 \%$ \\
\hline \multirow{3}{*}{ Hepatic } & None & 49 & $28.2 \%$ \\
Encepha- & Mild & 82 & $47.1 \%$ \\
lopathy & Gote to Severe & 43 & $24.7 \%$ \\
& Grade 1-2 & 174 & $100.0 \%$ \\
\hline
\end{tabular}

Table-I. Patients distribution according to age, gender, ascites and Hepatic Encephalopathy $n=174$

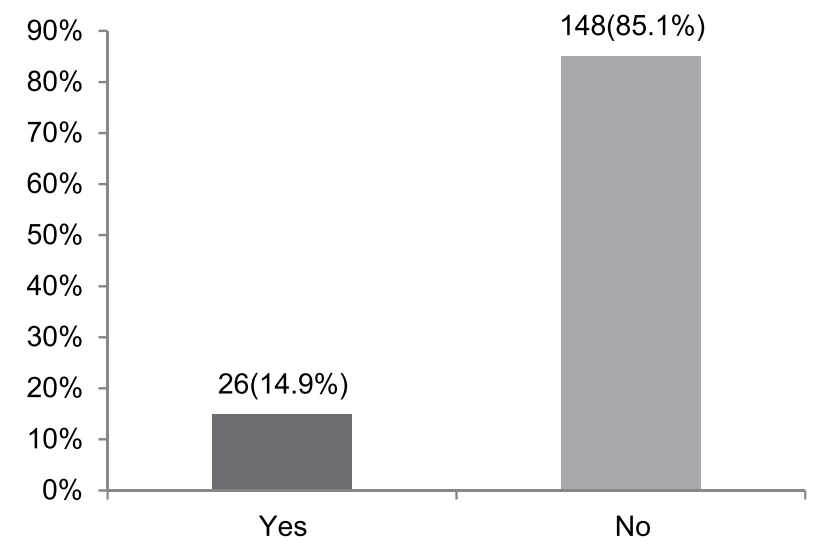

Figure-1. Frequency of spontaneous bacterial empyema in hydrothorax

\begin{tabular}{|c|c|c|c|c|c|}
\hline \multirow{2}{*}{\multicolumn{2}{|c|}{ Variables }} & \multicolumn{2}{|c|}{$\begin{array}{c}\text { Spontaneous } \\
\text { Bacterial Empyema }\end{array}$} & \multirow[t]{2}{*}{ Total } & \multirow[t]{2}{*}{ P-Value } \\
\hline & & Yes & No & & \\
\hline \multirow{2}{*}{ Gender } & Male & 17 & 89 & 106 & \multirow{2}{*}{0.391} \\
\hline & Female & 9 & 59 & 68 & \\
\hline \multirow{5}{*}{$\begin{array}{l}\text { Age } \\
\text { Groups }\end{array}$} & $<40$ & 0 & 1 & 1 & \multirow{5}{*}{0.017} \\
\hline & $41-50$ & 6 & 46 & 52 & \\
\hline & $51-60$ & 17 & 97 & 114 & \\
\hline & $61-65$ & 3 & 4 & 7 & \\
\hline & Total & 26 & 148 & 174 & \\
\hline
\end{tabular}

Table-II. Spontaneous Bacterial Empyema according to age and gender $n=174$

\section{DISCUSSION}

Spontaneous bacterial empyema may confound the course of hepatic hydrothorax, similarly as the unconstrained bacterial peritonitis confuses the course of the ascites among decompensated liver cirrhosis patients. Spontaneous bacterial empyema (SBEM) is a rare complication of portal hypertension with higher mortality rate. In this study spontaneous Bacterial Empyema among cirrhotic patients was found $14.9 \%$, which is less than Abbasi A et $\mathrm{al}^{12}$ as Bacterial Empyema among cirrhotic patients was $30.43 \%$. While our findings were similar to Xiol et $\mathrm{al}^{13}$, who enrolled the total 120 patients having cirrhosis, and SBEM found to be $13 \%$. Similarly Emam M et al ${ }^{14}$ reported that Spontaneous bacterial empyema was $14.3 \%$ out of 322 patients of cirrhosis. Some of these patients had massive hydrothorax which was treated with drainage of pleural fluid. In other study the rate of SBEM was found to be more or less similar. Chen $\mathrm{TA}$, et $\mathrm{al}^{9}$, reported that rate of SBEM in their patients was $13 \%$ among cirrhotic patients.

In this study out of all patients almost two thirds were in $6^{\text {th }}$ decade of their lives. Other studies have shown this is common age pattern of cirrhosis patients in our population. Abbasi $A$ et $\mathrm{al}^{12}$ reported that most of the patients $58.83 \%$ were more than 40 years of the age. Emam M et $\mathrm{al}^{14}$ also reported similar findings. The reason behind this is fact that most of these patients were infected with hepatitis $C$ virus about 2 to 3 decades ago (in their young age) when reuse of syringes at clinics of general practitioners. That infection with hepatitis followed by deficiency of diagnostic tools, lack of correct diagnosis and illiteracy resulted in development of chronic liver disease and the cirrhosis in these patients over a period of 20-30 years. Currently hepatitis C and chronic liver disease has become a major problem of our population and a great challenge for health system. It was also noted in our study that increasing age of patients was significantly associated with higher frequency of SBEM. This can be explained with fact that with increasing age there is decrease in immunity as well as advancement of chronic liver disease ( $P$-Value $<$ 0.017). 
In this study sixty percent patients were males while other were females. Sharma $V$ et $\mathrm{al}^{15}$ also found similar findings regarding age and gender. This again is typical finding of our population. Though women are slightly more in numbers in populations yet they are least exposed to complications of these chronic disorders. This may be due to their comparatively less exposure to injections which is due to social customs and males frequently expose to the barber shops, which also a strong risk factor for $\mathrm{HCV}$ transmission.

\section{CONCLUSION}

It was concluded that spontaneous bacterial empyema in cirrhosis patients was $14.9 \%$. There is a need of awareness programs among medical practitioners as well cirrhotic patients regarding early identifying and treating this complication so as unexpected deaths among these patients can be prevented.

\section{Copyright $\odot 31$ July, 2019.}

\section{REFERENCES}

1. Tu CY, Chen $\mathrm{CH}$. Spontaneous bacterial empyema. Curr Opin Pulm Med. Mar 2012; 23:355-58.

2. Allam NA. Spontaneous bacterial empyema in liver cirrhosis: An underdiagnosed pleural complication. Saudi J Gastroenterol. Jan 2008; 14(1):43-5.

3. Krok KL, Cardenas A. Hepatic hydrothorax. Semin Respir Crit Care Med. Feb 2012; 33(1):3-10.

4. Xiol X, Guardiola J. Hepatic hydrothorax. Curr Opin Pulm Med. Jul 1998; 4(4):239-42.

5. Wang JT, Fang CT, Hsueh PR, Chang SC, Luh KT. Spontaneous bacterial empyema caused by Aeromonas veronii biotype sobria. Diagn Microbiol Infect Dis. Aug 2000; 37(4):271-3.
6. Serrat J, Roza JJ, Planella T. Hepatic hydrothorax in the absence of ascites:respiratory failure in a cirrhotic patient. Anesth Analg. Dec 2004; 99(6):1803-4.

7. Doraiswamy V, Riar S, Shrestha P, Pi J, Alsumrain M, Bennet-Venner A, et al. Hepatic hydrothorax without any evidence of ascites. Sci World J. 2011; 11:587-91.

8. Cardenas A, Arroyo V. Mechanisms of water and sodium retention in cirrhosis and the pathogenesis of ascites. Best Pract Res Clin Endocrinol Metab. Dec 2003; 17(4):607-22.

9. Chen TA, Lo GH, Lai KH. Risk factors for spontaneous bacterial empyema in cirrhotic patients with hydrothorax. J Chin Med Assoc. Oct 2003; 66(10):57986.

10. Memon MS, A Burney, MH Ghani, ID Ujjan, U Soomro, $S$ Memon, et al. Frequency of Hepatic Hydrothorax in Patients with Liver Cirrhosis: A tertiary care hospital experience. J LUMHS. May-Aug 2009; 8(2):106-8.

11. Umer M, Bilal M. Hepatitis C, A Mega Menace: A Pakistani Perspective. JPMS. 2012, 2(2):68-72.

12. Abbasi A, Bhutto AR, Alam MT, Aurangzaib M, Masroor $M$. Frequency of hepatic hydrothorax and its association with child pugh class in liver cirrhosis patients. J Coll Physicians Surg Pak. 2016 Jul 1; 26(07):566-9.

13. Xiol X, Castellvi JM, Guardiola J. Spontaneous bacterial empyema in cirrhotic patients: A prospective study. Hepatology 1996; 23:719:23.

14. Emam M, Ibrahim A, Galal S, Darwish E. Study of frequency of spontaneous bacterial empyema in cirrhotic patients with hepatic hydrothorax. Journal of Gastroenterology and Hepatology Research. 2015 Apr 21; 4(4):1569-72.

15. Sharma V, Vijan Rai RS. Spontaneous bacterial empyema: An uncommon complication of liver cirrhosis. Journal of evolution of medical and dental sciences-jemds. 2015 Jul 27; 4 (60):10539-44. 


\title{
When you get to the peak, Remember the valley exists.
}

\author{
"Ernest Agyemang Yeboah"
}

\begin{tabular}{|c|l|l|l|}
\hline \multicolumn{3}{|c|}{ AUTHORSHIP AND CONTRIBUTION DECLARATION } \\
\hline Sr. \# & \multicolumn{1}{|c|}{ Author(s) Full Name } & \multicolumn{1}{|c|}{ Contribution to the paper } & Author(s) Signature \\
\hline 1 & Ehsan Rahim Memon & $\begin{array}{l}\text { Data collection and } \\
\text { manuscript writing. } \\
\text { Manuscript review. }\end{array}$ \\
\hline 2 & Prem Kumar Maheshwari & $\begin{array}{l}\text { Mata analysis and manuscript } \\
\text { Driting. }\end{array}$ \\
\hline 4 & Shabana Lakho & Zeeshan ul Haque & \begin{tabular}{l} 
Participation in data analysis. \\
\hline
\end{tabular} \\
\hline
\end{tabular}

